range of theoretical preoccupations, consider true intelligence to lie in good writing and not in writing that is merely complicated. Gone are the days when one can presume that a public for one's work exists or that once readers pick it up, they will dutifully read it to the end. In this time of unchecked overpublication, good style is not a luxury; it is increasingly a necessity.

Ross's unexpected response to the essay offers as good an argument as any for the ability of prose to reach beyond its author's subspecialty. For that, I am happy. For his part, Montaigne might have been amused that a study on "Of Cannibals" should appear "civilized."

George Hoffmann University of Michigan, Ann Arbor

\section{Milton on Defilement}

\section{TO THE EDITOR:}

In his article “'Lycidas': The Pastoral Elegy as Same-Sex Epithalamium" (117 [2002]: 222-36), Bruce Boehrer argues that in "Lycidas" Milton presents a "discomfort with feminine sexuality" (222) that amounts to viewing women as innately defiling (230-32). Certainly all would agree that in Milton's elegy women offer a distraction to the dedicated shepherd/poet - "sport with Amaryllis" and "the tangles of Neaera's hair" (68-69)—but to prove that they go beyond this and defile men, Boehrer leads us to one of the biblical sources for line 176, "and hears the unexpressive nuptiall song," in terms of which he reinterprets the whole poem. According to this source, Revelation 14.3-4, the unexpressive song could only be learned by those who "were not defiled with women: for they are virgins" (qtd. in Boehrer 227). If read literally, as Boehrer reads it, this verse strongly supports his argument, but in reading it literally Boehrer skates on thin hermeneutical ice.

It is doubtful whether anything in Revelation should be read literally, and it is clear that in Milton's day Protestants, who believed in a married clergy, rejected the literal reading of this particular verse altogether. The Geneva Bible (1560) glosses "defiled with women" as meaning "[b]y whoredome: and vnder this vice he comprehendeth all other: but this is chiefly meant of idolatrie which is the spiritual whoredome." If the passage in Revelation is read thus, marriage to a woman does not constitute defilement, consummation of marriage does not render a man any less a virgin, and all saints may learn the song, regardless of marital status or gender. Milton himself glossed the verse in $A n$ Apology for Smectymnuus (1642), in an autobiographical digression commonly anthologized but overlooked by Boehrer:

Nor did I slumber over that place expressing such high rewards of ever accompanying the Lamb with those celestial songs to others inapprehensible, but not to those who were not defiled with women, which doubtless means fornication; for marriage must not be called a defilement.

(Merritt Hughes, ed., John Milton: Complete Poems and Major Prose [Indianapolis: Odyssey, 1957] 695)

Clearly, therefore, women in themselves constitute no defilement, and Milton would no doubt admit among the chorus of heaven the saintly "Lady" of his Masque (1634), his "late espoused saint" of sonnet 19, and the ladies of sonnets 9 ("Lady, that in the prime of earliest youth") and 14 ("When Faith and Love, which parted from thee never"), who are said to attend the same heavenly wedding feast and enjoy the same immortal water as Lycidas. To Milton it is fornication, not feminine sexuality, that defiles.

Of course, one might object that An Apology was written five years after "Lycidas" and does not necessarily reflect Milton's earlier views. But the digression in An Apology is presented specifically as a record of his developing views of chastity from his youth up. Boehrer himself treats a work written two or three years after "Lycidas" as indistinguishable from its predecessor on the topic of female defilement. The paraphrastic rendering of this work, "Epitaphium Damonis," which Boehrer takes from The Riverside Milton, seems to reinforce his view. It portrays the deceased Damon as attaining heaven "[b]ecause your youth was without blame, because you never married" (qtd. in Boehrer 225). But Milton's "Quod nulla tori libata voluptas" (line 213) does not mean "because you never married" but "because you did not taste the delight of the marriagebed" (Hughes 139). The emphasis is on sexual delight, not marriage, and the bed (torus) is not even necessarily a marriage bed but any bed on which 
sexual pleasure, in or out of marriage, with femaleor male-might be enjoyed.

Indeed, had Damon and Lycidas not sported with but married Amaryllis and Neaera, the men might have found helps meet for their becoming better shepherds/poets and more worthy candidates for the celestial chorus - as long, that is, as neither let the tangles of his hair be shorn by his bride. Men are "the perfecter sex," Milton maintains in $A n$ Apology (695) and elsewhere, and must uphold their authority in marriage. But sexual union in marriage he declares pure, and he condemns those who "[d]efam[e] as impure what God declares / Pure, and commands to some, leaves free to all" (Paradise Lost 4.746-47). Milton's discomfort in and out of "Lycidas" is not with female sexuality but with female domination.

Kenneth Alan Hovey University of Texas, San Antonio

Reply:

I had hoped someone would challenge my essay by citing Milton's remarks on defilement in the Apology, and so I'm grateful to Kenneth Alan Hovey for giving me the opportunity to expand on this matter. While the ensuing comments necessarily emphasize the points on which we differ, I believe we are closer to agreement than might at first appear. I respect the thoroughness of his scholarship and the general moderation of his rhetoric.

Hovey's primary objection to my article involves its use of Revelation 14.3-4 to express discomfort with the possibility of feminine defilement. Citing the Apology and The Geneva Bible, Hovey argues to the contrary that this passage refers exclusively to fornication and cannot therefore be taken as evidence that Milton considered women to be a defilement "in themselves" (i.e., apparently, in wedlock).

Unfortunately, Hovey's evidence works against him. Note that the Geneva gloss to which he refers identifies the defilement of Revelation 14 "chiefly [as] idolatrie which is the spiritual whoredome" (my italics). As it happens, this is the lapse of which the Son convicts Milton's Adam in book 10 of Paradise Lost: "Was [Eve] thy God that her thou didst obey / Before his voice[?]" (10.146-47). By conceiving the defilement of Revelation 14 as primarily a spiri- tual rather than a carnal phenomenon, Milton by no means excludes it from the purview of wedlock; on the contrary, he makes an exegetical choice that will eventually lead him to identify such defilement as the original marital error.

From this standpoint it would appear to be Hovey, not I, who adopts an excessively literal reading of Revelation 14, a reading consonant with his apparent unwillingness to consider defilement as anything other than sexual relations and sexual relations as anything other than physical congress. Milton knew better, as a glance at the divorce tracts will make clear.

Nor does it follow, as Hovey seems to think, that because female contact may defile, therefore female contact must defile-any more than it follows that a fear of female defilement must lead one to exclude the ladies of the Maske and of sonnets 9, 14, and 19 from heaven on the basis of their gender. It is Hovey, not I, who describes women as "innately defiling," and I'm not overjoyed that he should attribute the phrase to me or to my view of Milton. What I do say-although Hovey overlooks it—is that Milton's verse expresses both "a longing for connubial union" (228) and "a concurrent aversion to feminine defilement" (231); again, just to make the point clear, I remark that Milton's sense of matrimony in "Lycidas" is "conflicted," in keeping with the anxieties embodied in the poet's later writing on marriage in general (233). Apparently Hovey dislikes such ambivalence and would prefer to see me promote an unconflicted, uncompromisingly misogynist view of the poet. Alas, I do not.

Bruce Boehrer Florida State University

\section{Kristeva and Derrida}

\section{To THE EDITOR:}

I was disappointed to read, in her interview with Alison Rice ("Forgiveness: An Interview" [117 (2002): 281-95]), Julia Kristeva's literal paraphrase of Jacques Derrida's thought on forgiveness: "Derrida dit en substance que, si on s'engage dans une réflexion sur le pardon et dans une pratique correspondant à cette réflexion, il faudrait pardonner l'impardonnable [...]" 'Derrida says that if one engages in this reflection on forgiveness and its practice, it 